\title{
EFEKTI ZUMBA FITNES PROGRAMA NA TJELESNU KOMPOZICIJU ŽENA
}

\section{Adriana Ljubojević1, Vladimir Jakovljević1 i Milijana Popržen²}

${ }^{1}$ Fakultet fizičkog vaspitanja i sporta, Univerzitet Banja Luka, Bosna i Hercegovina ${ }^{2}$ Firnes studio „Sport Trend“, Banja Luka, Bosna i Hercegovina

\section{SAŽETAK}

Cilj istraživanja je ispitati efekte osmonedeljnog zumba fitnes programa na promjene u tjelesnoj kompoziciji žena. Istraživanje je provedeno na uzorku 12 žena rekreativki starosne dobi od 25 do 35 godina u trajanju od osam nedelja (24 treninga). Prije i početka zumba fitnes programa izmjereni su sljedeći tjelesni parametri: tjelesna masa, postotak masnog tkiva, količina masnog tkiva izražena u kg, nemasna masa i ukupna količina vode u tijelu. Razlike aritmetičkih sredina na inicijalnom i finalnom mjerenju testirane su statističkom procedurom Paired sample $\mathrm{T}$ test. Rezultati su pokazali da je nakon osmonedeljne primjene zumba fitnes programa došlo do statistički značajnih promjena u smanjenju tjelesne mase $(p=0,019)$, zatim smanjenju postotka masnog tkiva $(p=0,012)$, te količine masnog tkiva izražene u $\mathrm{kg}(\phi=0,000)$. Iako su se vrijednosti nemasne mase $(0,22 \mathrm{~kg})$ i ukupne količinu vode u tijelu $(0,15 \mathrm{~kg})$ nakon provedenog programa uvećale, nisu bile statistički značajne. Zumba fitnes program pokazao se kao vrlo efikasno sredstvo vježbanja s ciljem redukcije masnog tkiva kod žena.

Ključne riječi: efekti vježbanja, tjelesna kompozicija, zumba fitnes

\section{UVOD}

Grupni fitnes programi predstavljaju oblik programiranog tjelesnog vježbanja žena s ciljem unapređenja zdravlja i poboljšanja estetskog izgleda. Zumba fitnes predstavlja spoj aerobnog vježbanja i latinoameričkih plesova koji se izvode uz zabavnu latino muziku. Objedunjuje osnovne principe aerobnog, intervalnog treninga i vježbi jačanja čime se pospješuje potrošnja kalorija, poboljšava rad kardiovaskularnog sistema i jača cijelo tijelo (Perez i Greenwood-Robinson, 2009). Ovakav koncept pristupa modernom fitnes vježbanju zadovoljava ciljeve kao što su harmonijsko oblikovanje tijela, poboljšanje držanja tijela, te učvršćivanje koštano-zglobnih i tetivnih segmenata lokomotornog sistema (Furjan-Mandić, Kosalec i Vlašić, 2011). Primjena različitih grupnih fitnes programa pokazala je značajne efekte u poboljšanju funkcionalnih i motoričkih sposobnosti (Mandarić, Sibinović, Mikalački i Stojiljković, 2011; Oreb, Matković, Vlašić, i Kostić, 2007; Park, Park, Kwon, Yoon i Kim, 2003; Šebić, Šahat, Zuković i
Lukić, 2012), kao i promjena u kompoziciji tijela žena (Donges, Duffield i Drinkwater, 2010; Stasiulis, Mockiene, Vizbaraite i Mockus, 2010; Wong i saradnici, 2002). Takođe, novija istraživanja kao posebno efikasan izdvajaju plesni fitnes program (Hižnayova, 2013; Oreb, Matković, Vlašić i Kostić, 2007; Kostić, Đurašković, Miletić i Makalčki, 2006; Kostić i Zagorc, 2005; Luettgen, Foster, Doberstein, Mikat i Porcari, 2012; Stoiljković, Mandarić, Todorović i Mitić, 2010; Viskic-Štalec, Štalec, Katić, Podvorac i Katović, 2007) u kojima se kroz motivirajuću muziku realizuju kreativne koreografije kojima je cilj da vježbača prvenstveno zabave. Prednost ovakvog modela vježbanja je u tome što je svaki trening nova zabava temeljena na pokretima i kretanjama različitog intenziteta i oblika što vježbače čini motivisanijim (Perez i Greenwood-Robinson, 2009). Ovo je vrlo važno s aspekta održavanja interesa za vježbanjem budući da je glavni razlog napuštanja grupno vođenih fitnes programa monotonija koja se javlja usljed jednoličnog ponavljanja gotovo identičnih časova u dužem periodu (Stoiljković i saradnici, 2010). Koji od brojnih fitnes sadržaja 
može da zadovolji zdravstveni, estetski, socijalni i zabavni karakter vježbanja i time privoli vježbače na dugoročno kontinuirano vježbanje pitanje je koji grupni fitnes instruktori često postavljaju. Cilj ovog istraživanja je ispitati efekte popularnog zumba fitnes programa na promjene u tjelesnoj kompoziciji žena.

\section{METODE}

\section{Uzorak ispitanika i varijabli}

Ispitivanje je provedeno na uzorku od 12 ispitanica, dobi od 25 do 35 godina. Za potrebe ovog istraživanja samo su selektovane ispitanice koje su pokazale $100 \%$-tni dolazak na treninge tokom 8 nedelja koliko je trajao zumba fitnes program. Program je proveden tokom aprila i maja mjeseca. Testiranje je vršeno u sportskoj sali Fakulteta fizičkog vaspitanja i sporta, prije početka i nakon završetka primjene zumba fitnes programa. Temperature sale se kretala oko $20^{\circ} \mathrm{C}$. Tokom trajanja programa ispitance nisu upražnjavale druge oblike fizičkog vježbanja. Testirane su prije i nakon provedenog programa vježbanja. Održana su 24 zumba fitnes treninga (časa) vođenih od strane licenciranog zumba fitnes instruktora. Za uporedivanje efekata primjene zumba fitnes programa na promjene u tjelesnoj kompoziciji izdvojene su sljedeće varijable: tjelesna masa (TM), postotak masnog tkiva (FAT), količina masnog tkiva izražena u kg (FATMASS), nemasna masa (FFM) koju čine mišići, kosti, tkiva i ostale nemasne mase i ukupna količina vode u tijelu (TBW).

\section{Zumba fitnes program}

Zumba treninzi održavali su se tri puta sedmično $\mathrm{u}$ večernjim terminima. Svaki zumba trening trajao je 60 minuta i sadržavao je osnovni koncept zumba vježbanja: zagrijavanje, glavni dio treninga, smirivanje i istezanje (Perez i Greenwood-Robinson, 2009). Intenzitet vježbanja određen je tempom muzike koji se mijenjao tokom treninga. Zagrijavanje traje od 8-10 minuta (2-3 muzičke numere, tempa 120-135 u/m), a izvodi se kroz osnovna kretanja (march, step touch, side to side) sa postepenim ubrzavanjem tempa muzike bez izvođenja skokova i poskoka. U drugom dijelu zagrijavanja izvode se vježbe snage umjerenim intenzitetom kroz plesne varijacije sa iskoracima $\mathrm{u}$ polučučnju (tempo muzike 125-140 u/m). Cilj zagrijavanja je podizanja tjelesne temperature, povećanje prokrvljenosti mišića, mobilizacija zglobova, ubrzanje rada kardio vaskularnog sistema, ali i psihološke pripreme za vježbanje. Glavni dio treninga izvodi se uz unaprijed pripremljenu zumba muziku (8-10 originalnih zumba pjesama) kojom se reguliše promjena tempa i dinamike izvođenja plesnih koreografija (tempo 140-160 u/m). U koreografiji smjenjuju se plesovi merengue, reggaeton, salsa, samba, belly dance, ča-ča-ča, tango idr. Plesovi traju između 3-5 min, a pauze između plesova traju od 15-30 sek. Svi latinoamerički plesovi međusobnose razlikuju po karakteru kretanja i dinamici izvođenja (Lukić, 2006). Cilj glavnog dijela časa je da vježbači uživaju u muzici i plesu istovremeno vježbajući. Smirivanje kao završni dio treninga podrazumijeva izvođenje laganih plesnih pokreta uz umirujuće tonove muzike s ciljem postepenog spuštanja srčane frekvencije, mentalnog i psihičkog opuštanja (tempo do $100 \mathrm{u} / \mathrm{m}$ ). Pokreti su smireniji, nema skokova i poskoka, i manje je pokreta rukama iznad glave. Istezanje se izvodi za opuštanje mišića i prevencija mišićne upale, ali i razvoja fleksibilnosti. Može se izvoditi u stojećem, sjedećem ili ležećem položaju. U kreiranju zumba programa vodilo se računa postepenom povećanju intenziteta vježbanja kako se organizam vježbačica adaptirao na opterećenja prethodnih treninga. Intenzitet vježbanja doziran je upotrebom bućica (Zumba toning program) ali i usložnjavanjem aerobik kretanja i plesnih pokreta u koreografijama.

\section{Opis mjerenja}

Svi parametri tjelesne kompozicije mjereni su pomoću analizatora tjelesne kompozicije marke TANITA tip BC-418MA III. Ispitanice su testirane u sportskoj opremi, odnosno helankama i majici. Unesena težina opreme u softver aparata iznosila je 0,300 g. Bosim nogama stajale su na donji dio analizatora sastava tijela, u rukama su držale elektrode. U aparat su unesene tjelesna visina i godine starosti, a za testiranje je odabrana je kategorija „standard” koja se odnosi na nesportiste. Nakon puštanja signala istosmjerna struja prolazi kroz tijelo i analizira potrebne parametre.

\section{Satistička obrada podataka}

Podaci prikupljeni tokom istraživanja obrađeni su pomoću aplikacionog statističkog programa za personalne računare IBM SPSS 20.0. Za analizu osnovnih statističkih podataka i distribucije rezultata na inicijalnom i finalnom mjerenju izračunati su osnovni deskriptivni parametri: aritmetička sredina, standardna greška aritmetičke sredine, min i max rezultat, standardna devijacija, K-S test normalnosti distribucije rezultata. Za izračunavanje razlika aritmetičkih sredina na inicijalnom i finalnom mjerenju, odnosno utvrđivanje efekata primjenjenog grupnog fitnes programa poslužio je Paired Sample T test. Značajnost zaključivanja utvrđena je na nivou $p<0,05$. 


\section{REZULTATI}

Deskriptivna statistika prikazana u Tabeli 1 ukazuje na promjene vrijednosti testiranih parametara nakon primjene osmonedeljnog zumba fitnes programa. Tjelesna masa u prosjeku je smanjena za $0,77 \mathrm{~kg}$, postotak masnog tkiva smanjen je za 1,05\%, ukupna količina masnog tkiva smanjena je za $1,01 \mathrm{~kg}$, nemasna masa koja se sastoji od mišića, kosti, tkiva, vode svih ostalih nemasnih masa povećala se za $0,22 \mathrm{~kg}$, ukupna količina vode u tijelu povećala se za $0,15 \mathrm{~kg}$. Testiran je normalitet raspodjele rezultata (K-S test) koji ukazuje na normalnost raspodjele dobijenih rezultata.

\section{TABELA 1}

Deskriptivna statistika parametara kompozicije tijela izmjerena na inicijalnom i finalnom mjerenju.

\begin{tabular}{|c|c|c|c|c|c|c|c|c|}
\hline & & $n$ & $M$ & Min & $\operatorname{Max}$ & $S D$ & $S E$ & $K-S$ \\
\hline \multirow{5}{*}{$\begin{array}{l}\text { 晃 } \\
\text { 早 }\end{array}$} & TM & 12 & 66,85 & 59,10 & 83,60 & 8,30 & 2,39 & 0,47 \\
\hline & FAT & 12 & 30,05 & 24,90 & 38,70 & 4,59 & 1,32 & 0,77 \\
\hline & FATMASS & 12 & 20,83 & 15,20 & 32,40 & 5,49 & 1,58 & 0,57 \\
\hline & FFM & 12 & 46,48 & 43,40 & 56,10 & 3,74 & 1,08 & 0,49 \\
\hline & TBW & 12 & 34,03 & 31,80 & 41,10 & 2,74 & 0,79 & 0,47 \\
\hline \multirow{5}{*}{ 案 } & TM & 12 & 66,08 & 58,20 & 83,50 & 8,35 & 2,41 & 0,63 \\
\hline & FAT & 12 & 29,00 & 24,00 & 36,70 & 4,08 & 1,17 & 0,37 \\
\hline & FATMASS & 12 & 19,37 & 13,90 & 30,60 & 4,90 & 1,41 & 0,64 \\
\hline & FFM & 12 & 46,70 & 43,50 & 58,40 & 4,46 & 1,28 & 0,23 \\
\hline & TBW & 12 & 34,18 & 31,80 & 42,80 & 3,28 & 0,94 & 0,24 \\
\hline
\end{tabular}

Legenda: n - Broj ispitanika; M - Aritmetička sredina; Min - Minimum; Max - Makimium; SD - Standardna devijacija; SE - Standardna greška; K-S - Test normaliteta raspodjele dobijenih rezultata; TM - Tjelesna masa; FAT - Postotak masnog tkiva; FATMASS

- Količina masnog tkiva izražena u kg; FFM - Nemasna masa; TBW - Ukupna količina vode u tijelu; Initaial - Inicijalno, Final - Finalno.

TABELA 2

Efekti primjenjenog qumba fitnes programa na promjene u tjelesnoj kompoziciji žena.

\begin{tabular}{|c|c|c|c|c|c|c|c|c|c|}
\hline & \multicolumn{5}{|c|}{ Paired Differences } & \multirow{4}{*}{$t$} & \multirow{4}{*}{$d f$} & \multirow{4}{*}{$p$} \\
\hline & & \multirow{3}{*}{$M$} & \multirow{3}{*}{$S D$} & \multirow{3}{*}{$S E$} & \multirow{2}{*}{\multicolumn{2}{|c|}{$\begin{array}{l}95 \% \text { Confidnece Inter- } \\
\text { val of the Differnece }\end{array}$}} & & & \\
\hline & & & & & & & & & \\
\hline & & & & & Lower & Upper & & & \\
\hline Pair 1 & TMI-TMF & 0,77 & 0,97 & 0,28 & 0,15 & 1,39 & 2,75 & 11 & $-0,01$ \\
\hline Pair 2 & FATI-FATF & 1,05 & 1,20 & 0,34 & 0,28 & 1,81 & 3,00 & 11 & 0,01 \\
\hline Pair 3 & FATMASSI - FATMASSF & 1,00 & 0,92 & 0,26 & 0,42 & 1,59 & 3,78 & 11 & 0,00 \\
\hline Pair 4 & FFMI-FFMF & $-0,22$ & 1,13 & 0,32 & $-0,94$ & 0,49 & $-0,68$ & 11 & 0,50 \\
\hline Pair 5 & TBWI-TBWF & $-0,15$ & 0,83 & 0,24 & $-0,68$ & 0,38 & $-0,62$ & 11 & 0,54 \\
\hline
\end{tabular}

Legenda: M - Aritmetička sredina; SD - Standardna devijacija; SE - Standardna greška; t Studenova t distribucija; df - Stepeni slobode; $\mathbf{p}$ - Vjerovatnoća; TMI - Tjelesna masa inicijalna; TMF - Tjelesna masa finalna; FATI - Postotak masnog tkiva inicijalnai; FATF - Postotak masnog tkiva finalni; FATMASSI - Količina masnog tkiva izražena u kg inicijalna; FATMASSF - Količina masnog tkiva izražena u kg finalna; FFMI Nemasna masa inicijalna; FFMF - Nemasna masa finalna; TBWI - TUkupna količina vode u tijelu inicijalna; TBWI - Ukupna količina vode u tijelu finalna; Pair - Par; Paired Differences - Uparene razlike; 95\% Confidnece Interval of the Differnece - Interavla povjeranja razlika; Lower - Donji; Upper - Gornji. 
U Tabeli 2 prikazani su efekti osmonedeljnog zumba fitnes programa na promjene u tjelesnoj kompoziciji žena. Rezultati pokazuju da postoji statistički značajna razlika na finalnom u odnosu na inicijalno mjerenje kod sljedećih varijabli: tjelesna masa $(0,01)$, postotak masnog tkiva $(0,01)$ i ukupna količina masnog tkiva izražena u $\mathrm{kg}(0,00)$. Iako su u Tabeli 1 prikazane uvećane vrijednosti aritmetičkih sredina nemasne mase $(0,22 \mathrm{~kg})$ i ukupne količine vode u tijelu $(0,15$ $\mathrm{kg})$ na finalnom mjerenju, one se nisu pokazale kao statistički značajne ( $\mathrm{FFM} p=0,50$; TBW $p=0,54$ ).

\section{DISKUSIJA}

Očigledno da je primjenjeni zumba fitnes program vježbanja izazvao značajne promjene u nekim posmatranim parametrima tjelesne kompozicije žena. Ove promjene se ogledaju prvenstveno u smanjenju tjelesne mase $(p=0,01)$, smanjenju postotka masnog tkiva $(p=0,01)$ i ukupne količine masnog tkiva izražene $\mathrm{u}$ $\mathrm{kg}(p=0,00)$. Uvidom u Tabelu 1 primjenjeni zumba program najviše efekata ostvario je na postotak masnog tkiva koji je smanjen za 1,05\% i gubljenje masnog tkiva u prosjeku $-1,01 \mathrm{~kg}$. Tjelesna težina u prosjeku je smanjena za $0,77 \mathrm{~kg}$. Upoređujući zumba fitnes vježbanje sa tae bo aerobikom Hižnayova (2013) ispituje razlike u intenzitetu vježbanja. Ispitivanje je provedeno na 11 žena tokom 6 treninga zumbe i 6 treninga tae bo aerobika. Dobijeni podaci srčane frekvencije procjenjivani su u 3 glavna dijela treninga: nakon zagrijavanja, u glavnom dijelu treninga i nakon opuštanja i istezanja. Rezultati pokazuju je intenzitet vježbanja tokom zagrijavanja i glavnog dijela treninga statistički značajno veći u svih 6 zumba treninga u odnosu na tae bo aerobic $(p<0,05)$. Potrošnja energije (izmjerena u kilokalorijama) tokom svih treninga, takođe, značajno je veća u korist zumba fitnes modela vježbanja $(p<0,01)$. Slični rezultati dobijeni su i u istraživanjima Barene, Krustrup, Jackman, Brekke i Holtermann (2013) koji su ispitivali efekte dvanaestonedeljnog zumba fitnes programa na postotak masne mase i ukupnu količinu masne mase na uzorku žena zaposlenih u zdravstvenom sektoru. Aktivnosti su upražnjavale 2-3 sata nedeljno. Rezultati su pokazali da je grupa koja je provodila zumba fitnes značajno smanjila ukupnu količinu masne mase $(-0,6 \mathrm{~kg}$, $p<0,05)$ u odnosu na kontrolnu grupu. Generalno zaključuju da upražnjavanje zumba fitnes modela vježbanja izvan radnog vremena može dovesti do određenih zdravstvenih beneficija kod žena zaposlenih u zdravstvu. Zumba fitnes program vježbanja, uzmeđu ostalog, temelji se i na raznovrsnosti zumba sadržaja (zumba klasik, zumba gold, zumba toning, zumba sentao, zumba kids itd) u kojima se složenost plesnih koreografija i intenzitet opterećenja adaptira starosnoj dobi i ciljevima koji se žele vježbanjem ostvariti. Posebno je potrebno naglasiti da je provedeno istraživanje efekata zumba fitnes programa u relativno kratkom vremenskom periodu od 8 nedelja izazvao statistički značajne promjene u tjelesnoj kompoziciji žena, što nije zanemarljivo ukoliko znamo da je motiv pojedinim vježbačima da pristupe grupnim fitnes programima upravo redukcija masne mase i gubitak kilograma.

\section{ZAKLJUČAK}

Istraživanje osmonedeljnog zumba fitness programa na uzorku žena rekreativki pokazalo je statistički značajne efekte na promjene u tjelesnoj kompoziciji žena. One se ogledaju u smanjenju tjelesne mase, smanjenju postotka masnog tkiva i smanjenju ukupne količine masnog tkiva izraženog u kg. Iako je zumba fitnes program proveden u trajanju od 8 nedelja njegova primjena pokazala je efikasnost u redukciji masnog tkiva, što je vrlo značajno budući da je to vrlo čest motiv pristupanja grupnim fitnes programima. Posebnost zumba fitnes programa ogleda se u raznovrsnim koreografijama latinoameričkih plesova i dinamičnoj muzici koja stvara atmosferu zabave (zumba party) u kojima vježbači zaborave da vježbaju, a ovakav pristup vježbanju omogućava dugoročnu zainteresovanost i kontinuirano vježbanje. Bilo bi zanimljivo ispitati efekte zumba fitnes programa na redukciju masnog tkiva pojedinih segmenata trupa $i$ kaudalnog dijela tijela posmatranih u dužem periodu provođenja programa i kontinuiranom vježbanju (minimalno 3x nedeljno). Takode, bilo bi interesantno uporedivati efektivnost primjene zumba fitnes programa u odnosu na druge fitnes sadržaje. Treba napomenuti da je istraživanja efekata zumba fitnes vježbanja jako malo u poređenju sa istraživanjima drugih aerobik sadržaja. To je iz razloga što je zumba fitnes posljednji "hit" koji se pojavio u domenu grupnog fitness vježbanja i da se njegovi stvarni efekti na različitim populacijamai u različite svrhe tek trebaju ispitivati. Ovaj rad je mali doprinos rasvjetljavanju njegove stvarne efektivnosti u promjenama tjelesnih parametara žena.

\section{LITERATURA}

Barene, S., Krustrup, P., Jackman, S. R., Brekke, O. L., \& Holtermann, A. (2013). Do soccer and zumba exercise improve fitness and indicators of health among female hospital employees? A 12-week RCT. Scandinavian Journal of Medicine do 
Science in Sports on line. Retrived from http:// onlinelibrary.wiley.com/doi/10.1111/ sms.12138/full. doi: 10.1111/sms.12138

Donges ,C. E., Duffield, R., \& Drinkwater, E. J. (2010). Effects of resistance or aerobic exercise training on interleukin-6, C-reactive protein, and body composition. Medicine and Science in Sport and Exercise, 42(2), 304-413. doi: 10.1249/ MSS.0b013e3181b117ca; PMid: 20083961

Furjan-Mandić, G., Kosalec, V., \& Vlašić, J. (2011). The effects of aerobic exercise on the increase of repetitive strength in women. In S. Simović (Ed.), 3th International aspects of Sports, Physical education and Recreation (pp. 75-83). Banjaluka, Bosnia and Herzegovina: Faculty of Physical Education and Sport. doi: 10.5550/SP.3.2011.09

Hižnayova, K. (2013). Exercise intensity during zumba fitness and tae bo aerobics. Journal of Human Sport and Exercise, 8(2), S228-S241. doi: 10.4100/jhse.2012.8.Proc2.26

Kostić, R., Đurašković, R, Miletić, Đ., \& Makalački, M. (2006). Changes in cardiovascular fitness and body composition of women under the influence of dance aerobic. Facta Universitatis, 4(1), 59-71.

Kostić, R., \& Zagorc, M. (2005). Comparison of changes in cardiovascular fitness two models of aerobic exercise of women. Facta Universitatis, 3(1), 45-57.

Lukić, A. (2006). Realcije irmedu motoričkih sposobnosti i efikasnosti izvodenja osnovnih elemenata tehnike u sportskom plesu [The relationship between motor skills and performance efficiency of the basic technique steps in sport dance]. Unpublished master's thesis. Universita of Banja Luka, Faculty of Physical Education and Sports.

Luettgen, M., Foster, C., Doberstein, S., Mikat, R., \& Porcari, J. (2012). Zumba: Is the "fitnessparty" a good workout? Journal of Sports Science and Medicine, 11(2), 357-358. PMid: 24137072; PMCid: PMC3737860

Mandarić, S., Sibinović, A., Mikalački, M., \& Stojiljković, S. (2011). The effects of the program HI-Low aerobics on morphological characteristics and functional ability students in the eight grade. Journal of Sports science and Health, 1(1), 18-23.

Oreb, G., Matković, B., Vlašić, J., \& Kostić, R. (2007). The structure of the functional abilities of the dancers. Croatian sports herald, 9(1), 16-23

Park, S. K., Park, J. H, Kwon, Y. C., Yoon, M. S., \& Kim, C. S. (2003). The effects of long-term aerobic exercise on maximal oxygen consumption, left ventricular function and serum lipids in elderly women. Journal of Physiological Anthropology and applied Human Science, 22(1), 11-17. doi: 10.2114/jpa.22.11; PMid: 12672978

Perez, B., \& Greenwood-Robinson, M. (2009). Zumba: Ditch the workout, join the party! The Zumba weight loss program. New York, NY: Maggie Greenwood-Robinson.

Stasiulis, A., Mockiene, A., Vizbaraite, D., and Mockus, P. (2010). Aerobic exercise-induced changes in body composition and blood lipids in young women. Medicine, 46(2), 129-134.

Stoiljković, S., Mandarić, S., Todorović, K., \& Mitić, D. (2010). The effects of "Omnibus" aerobics program on body composition of women. Physical Culture, 64(2), 59-67.

Šebić, L., Šahat, S., Zuković, A., \& Lukić, A. (2012). Coordination tests predictive value on success during the performance of dance and aerobics motion structures. Homosporticus, 14(1), 22-26.

Viskić-Štalec, N., Štalec, J., Katić, R, Podvorac, D., \& Katović, D. (2007). The impact of danceaerobic training on the morpho-motor status in female high-scholars. Collegium Antropologicum, 31(1), 259-266. PMid: 17598411

Primljeno: 13. mart 2014 Izmjene primljene: 30. maj 2014

Odobreno: 23. jun 2014

Korespondencija: Dr Adriana Ljubojević

Fakultetb fizičkog vapsitanja i sporta Univerzitet u Banja Luci

Bulevar Vojvode Petra Bojovića 1a 78000 Banja Luka

Bosna i Hercegovina

Telefon: +38765567612

E mail: adri.ljubojevic@gmail.com 